\title{
Hubungan antara Status Gizi, Risiko Anemia, dan Ketahanan Pangan dengan Produktivitas Pekerja Bangunan
}

\section{Correlation between Nutritional Status, Risk of Anemia, and Food Security with Construction Workers Productivity}

\author{
Mohammad Fahmi Rasyidi*1 ${ }^{1}$, Trias Mahmudiono ${ }^{1}$, Qonita Rachmah ${ }^{1}$
}

\begin{abstract}
ABSTRAK
Latar Belakang: Produktivitas merupakan suatu upaya atau kemampuan yang diberikan oleh suatu individu dalam menghasilkan barang atau jasa. Pekerjaan konstruksi bangunan merupakan jenis pekerjaan yang secara kualitas memerlukan kondisi fisik dan stamina yang prima untuk lebih produktif dalam bekerja. Banyak faktor yang mempengaruhi produktivitas kerja salah satu diantaranya ialah melalui aspek gizi dan kesehatan seperti status gizi, anemia, dan kondisi ketahanan pangan. Beberapa faktor tersebut akan secara langsung maupun tidak langsung berpengaruh terhadap perbedaan kondisi produktivitas dalam pekerja bangunan.

Tujuan: Menganalisis hubungan antara status gizi, risiko anemia, dan ketahanan pangan dengan produktivitas kerja pada pekerja bangunan di wilayah Perumahan Graha Natura, Surabaya.

Metode: Penelitian cross sectional ini melibatkan 65 orang pekerja yang terpilih secara acak dengan teknik simple random sampling. Proses pengambilan data dilakukan melalui wawancara untuk variabel ketahanan pangan, pengukuran antropometri untuk variabel status gizi dan pemeriksaan tanda dan gejala klinis untuk variabel risiko anemia. Selain itu penilaian variabel produktivitas dilakukan dengan metode wawancara terkait hasil kerja berupa input maupun output. Analisis data yang digunakan yaitu dengan uji statistik chisquare. Penelitian ini fokus kepada variabel bebas yakni status gizi, risiko anemia, dan ketahanan pangan serta variabel tetap yaitu produktivitas kerja.

Hasil: Hasil penelitian menunjukkan adanya hubungan antara risiko anemia pekerja $(\mathrm{p}<0,001)(\mathrm{r}=0,656)$ dengan produktivitas kerja, sedangkan status gizi dan ketahanan pangan tidak memiliki hubungan dengan produktivitas kerja [status gizi $(\mathrm{p}=0,826)$, status ketahanan pangan $(\mathrm{p}=0,282)$ ].

Kesimpulan: Penelitian ini menyimpulkan bahwa risiko anemia pada pekerja berhubungan dengan produktivitas dalam bekerja. Peningkatan asupan tinggi kalori dan seimbang perlu untuk diterapkan oleh pekerja untuk meningkatkan stamina dalam menjaga produktivitas kerja.
\end{abstract}

Kata kunci: status gizi, risiko anemia, ketahanan pangan, produktivitas kerja

ABSTRACT

Background: Productivity is an ability given by an individual to produce goods or services. Building construction work is a type of work that requires physical condition and stamina to be more productive in work. Many factors that affect work productivity are nutrition and health aspects such as nutritional status, risk of anemia, and food security condition. Some of these factors will directly or indirectly affect work performance.

Objectives: The study aimed to analyze the relationship between nutritional status, risk of anemia, and food security with work productivity in construction workers.

Methods: This cross-sectional study involved 65 construction workers selected with a simple random sampling technique. The data retrieval process conducted through interviews for food insecurity variables, anthropometry measurements for nutrition status variable, and assessment of clinical signs and symptoms for the risk of anemia. Meanwhile, the productivity assessment variable conducted by interview method 
related to work results in input and output. The analysis of data used was the chi-square test adjusted to the type of data scale obtained. This study focuses on independent variables: nutritional status, risk of anemia, and food security and the dependent variable was work productivity.

Results: The results showed significant relationships between risk of anemia $(p<0.001)(r=0.656)$ with work productivity. Nutritional status and food security were not significantly related to productivity of construction workers [nutritional status $(p=0.826)$, food security status $(p=0.282)$ ]

Conclusions: This study revealed that the risk of anaemia among workers was related to work productivity. Food high calorie and balanced intake need to be applied to increase stamina in maintaining work productivity.

Keywords: nutrition status, risk of anaemia, food security, work productivity

\author{
*Koresponden: \\ m.fahmirasyidi@gmail.com \\ Mohammad Fahmi Rasyidi \\ ${ }^{1}$ Departemen Gizi Kesehatan, Fakultas Kesehatan Masyarakat, Universitas Airlangga, Kampus C \\ Mulyorejo,60115, Surabaya, Jawa Timur, Indonesia
}

\title{
PENDAHULUAN
}

Permasalahan dalam kualitas kerja seorang pekerja masih menjadi pokok persoalan yang perlu diperhatikan oleh sebuah perusahaan. Kinerja seorang pekerja dapat diukur melalui tingkat produktivitas dalam melakukan pekerjaan. Berdasarkan data yang didapatkan dari Cencus and Economic Information Center (CEIC)yang berjudul "Indonesia Labour Productivity Growth" diketahui angka produktivitas tenaga kerja di Indonesia berada dalam angka 2,4 \% menurut angka domestik bruto (PDB) pada tahun 2018. Hal ini jika dibandingkan pada tahun 2017 terjadi penurunan yakni sebesar 0,4\% dari angka 2,8\%(Census and Economic Information Center, 2017). Apabila ditinjau kembali melalui data pusat statistik di Indonesia tahun 2018, pertumbuhan laju Produk Domestik Bruto (PDB) didapatkan sebesar 2,64 poin, berbeda jauh dibandingkan pada tahun 2015 sebesar 4,7 poin(Badan Pusat Statistik, no date). Dalam ruang lingkup lebih dalam lagi, provinsi Jawa Timur juga didapati terjadi penurunan yang pada tahun 2015 sebesar 5,11 poin turun hingga menjadi 3,69 poin pada tahun 2018. Berdasarkan gambaran data sebelumnya, fokus dalam meningkatkan produktivitas pada pekerja menjadi hal yang perlu diupayakan oleh suatu perusahan dalam menciptkan kualitas pekerja yang baik.

Pengertian mengenai produktivitas dijelaskan secara sederhana oleh International Labour Organization (ILO) yakni merupakan pemanfaatan sumber daya secara efektif untuk meningkatkan nilai tambah dalam barang dan jasa (International Labour Organization, 2015). Dalam penjelasan lain juga disebutkan bahwa produktivitas ialah ukuran yang didapatkan dalam suatu kegiatan dalam mencapai target kuantitas dan kualitas yang telah ditentukan (Tisnawati and Kurniawan, 2005). Secara umum, produktivitas merupakan hasil perbandingan antara output (hasil) dan input (masukan atau upaya). Dalam pekerjaan di bidang konstruksi, aspek output dapat dilihat melalui kuantitas pekerjaan seperti pada hasil pekerjaan yang dihasilkan, misalnya pemasangan bata, pengecoran beton dan atau yang lainnya. Selain itu dari aspek input merupakan jumlah sumber daya yang dipergunakan seperti tenaga kerja, peralatan dan material (Astawa, 2015). Sebagai upaya dalam meningkatkan produktivitas pekerja, suatu perusahaan perlu memperhatikan beberapa aspek salah satunya ialah dalam segi gizi dan kesehatan. Kualitas kesehatan seorang pekerja sangat mempengaruhi kualitas kerja yang dihasilkan. Aspek gizi dan kesehatan menjadi fokus yang perlu untuk diperhatikan pada seorang pekerja dalam meningkatkan produktivitas kerja.

Kecukupan gizi pada pekerja memiliki peranan yang sangat penting dalam menjaga daya tahan tubuh untuk meningkatkan perfoma dalam bekerja. Kebutuhan gizi akan menjadi gambaran terhadap kondisi status giziyang dimiliki oleh pekerja. Pemenuhan akan kebutuhan gizi pekerja merupakan salah satu bentuk penerapan syarat kesehatan dan keselamatan kerja (K3) dalam sebuah pekerjaan yang memiliki peranan penting dalam meningkatkan nilai produktivitas (Ratnawati, 2011). Penelitian yang dilakukan oleh Riyani dan Ardyanto (2016) juga menunjukkan bahwa status gizi mempunyai hubungan dengan produktivitas kerja sehingga faktor ini perlu mendapatkan perhatian khusus (Riyani and Ardyanto, 2016). Dalam penelitian lain juga menunjukkan bahwa permasalahan status gizi kurang pada pekerja akan mengakibatkan meningkatnya kerentanan dalam kondisi tubuh yang cepat lelah dan lesu, stress mental terganggu, hingga produktivitas dalam bekerja menurun serta menyebabkan target kerja tidak tercapai(Danan Surya Fitriananto et al., 2018). Kondisi kesehatan lainnya yang turut menjadi masalah pekerja dalam melakukan aktivitasnya salah satunya yakni anemia. 
Penelitian yang dilakukan oleh Fitri (2016) menyebutkan bahwa anemia pada pekerja dapat menimbulkan kelelahan, penurunan kapasitas dan produktivitas kerja (Fitri, 2016). Sebagaimana yang disebutkan pula oleh Laluyan dkk (2016) yang menjelaskan bahwa adanya anemia akan berpotensi terhadap menurunya konsentrasi dan kelelahan pada tubuh seseorang (Laluyan, Paruntu and Assa, 2016). Kejadian anemia pada pekerja jika dilihat kembali kebelakang, dapat dipengaruhi oleh adanya ketidakcukupan asupan gizi yang beragam maupun faktor kesehatan yang lainnya. Kurang beragamnya asupan makanan merupakan salah satu faktor karena

kurangnya akses terhadap pangan. Akses terhadap pangan yang beragam menjadi salah satu indikator dalam mengukur tingkat ketahanan pangan pada suatu individu.

Ketahanan pangan menjadi salah satu aspek dalam menilai tolak ukur seseorang dalam kemampuan akses konsumsi terhadap pangan. Okoye, dkk (2016) dalam penelitiannya menunjukkan bahwa ketahanan pangan memiliki pengaruh pada produktivitas pekerja dalam melakukan aktivitas (Okoye B and Bachwenkizi, 2016). Kondisi ketahanan pangan yang baik akan mendorong seseorang atau pekerja untuk dapat mencukupi atau mengakses pangan untuk memenuhi kebutuhan gizi melalui asupan makan yang baik, sehingga akan lebih produktif dalam menjalankan suatu aktivitas atau pekerjaan. Seseorang akan terpenuhi kebutuhan gizinya apabilaindividu tersebut mendapatkan kemudahan dalam memperoleh akses pangan yang cukup(Sutomo, Purwaningsih and Daerobi, no date).

Proyek konstruksi ialah pekerjaan yang identik dengan kemampuan fisik dalam melakukan aktivitasnya. Pekerja bangunan dituntut untuk selalu memiliki daya tahan tubuh yang prima dalam menjalankan setiap bagian kerja yang diberikan. Kebutuhan akan gizi dan kesehatan menjadi perhatian penting dalam menunjang kemampuan pekerja untuk lebih produktif dalam bekerja. Dengan demikian, penulis tertarik untuk mempelajari hubungan antara status gizi, status anemia, dan ketahanan pangan pada pekerja dengan produktivitas dalam bekerja di lapangan.

\section{METODE}

Penelitian ini berlangsung di perumahan Graha Natura, Sambikerep, Surabaya. Perumahan ini dipilih karena merupakan salah satu perumahan yang sedang dilakukan pengembangan proyek pembangunan. Lokasi proyek ini melibatkan sejumlah 4 kontraktor dengan total populasi sejumlah sekitar 150 orang pekerja. Status pekerja yang dipergunakan dalam proyek ini yakni dengan sistem pekerja lepas yang mana tidak ada ikatan kontrak dalam jangka waktu tertentu. Penelitian ini menggunakan desain cross sectional, dengan populasi pekerja konstruksi pada Perumahan Graha Natura, Sambikerep, Surabaya Barat yang dipilih secara purposif atas pertimbangan di perumahan tersebut sedang dilakukan pengembangan proyek bangunan rumah tambahan.

Besar sampel dihitung dengan rumus estimasi proporsi(Masturoh and Anggita, 2018), dan diperoleh sebesar 65 orang. Hasil perhitungan sampel ini telah ditambahkan persentase sejumlah $10 \%$ untuk mengantisipasi adanya bias dalam pengambilan data. Teknik pengambilan data dalam penelitian ini menggunakan simple random sampling atau metode acak sederhana. Penelitian ini dilaksanakan pada bulan April hingga Mei 2020 setelah memperoleh persetujuan etik dari komisi etik Fakultas Kedokteran Gigi, Universitas Airlangga, Surabaya dengan No: 133/HRECC.FODM/III/2020.

Proses pengambilan data dalam penelitian ini terbagi dalam tiga kegiatan yakni pengukuran, wawancara, dan pengamatan langsung terhadap responden (pekerja bangunan). Pengukuran yang dilakukan yakni dengan menilai risiko anemia dan mengukur status gizi pada pekerja. Prosedur penilaian risiko anemia dilakukan denganmenggunakan metode uji tanda dan gejala klinis atau pengamatan terhadap bagian tubuh yang memiliki indikasi terhadap risiko anemia(Thamaria, 2017). Penilaian tanda klinis ini mengacu kepada beberapa indikator atau acuan yang didapatkan menurut sumber dari Kemenkes, RI. dan Muhammad, dkk diantaranya adalah kuku rapuh, mata pucat, kulit pucat, stomatis bibir, gusi berdarah, pusing, lelah, mimisan, denging telinga, sakit kepala, sesak nafas, infeksi ringan, gangguan rasa, serta ingatan jangka pendek. Penilaian skor kategori risiko anemia ini berdasarkan atas Assessment Anaemia Questionnaire Aldine Independent School District. Pemeriksaan tanda gejala klinis dilakukan mandiri oleh peneliti dengan mengacu kepada pedoman Kemenkes,RI. Untuk penilaian risiko anemia di bedakan dalam 2 kategori yakni tidak resiko anemia ( $<7$ tanda gejala klinis) dan resiko anemia ( $>7$ tanda gejala klinis) (Assessment Anaemia Questionnaire Aldine IndependentSchool District, no date). Pengukuran risiko anemia pada pekerja ini dilakukan langsung bersama dengan pengukuran antropometri (status gizi) yakni pada waktu istirahat pekerja pukul 12.00 sampai 13.00.

Pengukuran status gizi dilakukan menggunakan metode antropometri melalui pengukuran berat badan dan tinggi badan. Penilaian status gizi berdasarkan atas Indeks Massa Tubuh (IMT) dengan perhitungan $\left[\mathrm{IMT}=\mathrm{BB}(\mathrm{kg}) / \mathrm{TB}(\mathrm{m})^{2}\right]$. Instrumen yang digunakan dalam pengukuran ini yaitu menggunakan timbangan digital merk vanstar dengan tingkat ketelitian $0,01 \mathrm{~kg}$ dan microtoice merk GEA seri SH-2A dengan tingkat keakuratan $1 \mathrm{~mm}$ untuk pengukuran tinggi badan. Klasifikasi untuk status gizi dalam 
penelitian ini terbagi dalam 3 kriteria diantaranya kurus $(<18,5)$, normal $(18,5-25)$, dan gemuk $(>25)$ (Kementerian Kesehatan RI, 2019). Proses wawancara ini dilakukan secara daring (online) diluar jam kerja pekerja karena dampak dari pandemi covid-19.

Status ketahanan pangan pekerja dinilai melalui instrumen Individual Dietary Diversity Score (IDDS) melalui proses wawancara. Proses wawancara ini dilakukan secara daring (online) diluar jam kerja pekerja karena dampak dari pandemi covid-19. Ketahanan pangan menurut FAO dibedakan dalam 3 kategori yaitu keragaman pangan tingkat rendah, sedang, dan tinggi (Kennedy, Ballard and Dop, 2013). Selain itu juga dilakukan observasi atau pengamatan terkait aktivitas kerja harian pekerja bangunan untuk menilai produktivitas kerja. Penilaian produktivitas pekerja dilakukan dengan melakukan perhitungan terhadap hasil kerja dengan target kerja harian yang telah ditetapkan (Input/output x 100\%). Dalam pekerja banguan, indicator produktivitas dilihat melalui capaian hasil kerja dalam satuan luas atau volume bangun, kemudian dilihat dengan target harian yang ditetapkan oleh mandor atau kepala proyek. Hasil penilaian tersebut kemudian akan dikategorikan dalam bentuk persentase sesuai dengan beban kerja yang dimiliki yakni $<50 \%=$ tidak produktif dan $>50 \%=$ produktif $^{32}$.. Analisis statistik yang digunakan ialah uji chisquare dengan penyajian data dalam bentuk hasil distribusi dan persentase.

\section{HASIL DAN PEMBAHASAN}

Sebaran data usia, pendapatan, dan kebiasaan merokok pekerja terlampir dalam tabel 1. Tabel 1 menyebutkan bahwa mayoritas usia pekerja adalah 30-49 tahun dan seluruhnya memiliki pendapatan dibawah UMK. Upah atau gaji yang diterima pekerja didasarkan atas kinerja dan target harian yang ditetapkan oleh kontraktor. Besaran gaji yang didapat juga akan berpengaruh terhadap hasil kerja harian yang telah dilakukan. International Labour Organization (ILO) menjelaskan bahwa pendapatan yang cukup akan meningkatkan performa pekerja menjadi lebih baik. Dengan demikian produktivitas pada pekerja akan berpengaruh terhadap besaran gaji yang didapatkan. Sebesar $40 \%$ pekerja rutin mengkonsumsi rokok sebanyak 1/2-1 pack per hari. Hal ini menunjukkan kebiasaan merokok pada pekerja bangunan masih tergolong tinggi. Kebiasaan merokok ini menurut WHO juga memiliki pengaruh terhadap kesehatan khususnya kepada kejadian anemia(World Health Organization (WHO), 2011). Jumlah frekuensi merokok pada seseorang akan mempengaruhi kadar hemoglobin dalam tubuh sehingga akan meningkatkan resiko terjadinya anemia.

Tabel 1. Karakteristik Responden Pekerja Bangunan

\begin{tabular}{lrr}
\hline Karakteristik & Jumlah (orang) & Persentase (\%) \\
\hline Usia & 1 & 1,5 \\
$16-18$ tahun & 10 & 15,4 \\
$19-29$ tahun & 40 & 61,5 \\
$30-49$ tahun & 14 & 21,5 \\
$>50$ tahun & 65 & 100,0 \\
\hline Total & & 0,0 \\
\hline Pendapatan & 0 & 100,0 \\
$\geq$ Rp. 4.200.000 & 65 & 100,0 \\
< Rp. 4.200.000 & 65 & 40,0 \\
\hline Total & & 40,0 \\
\hline Kebiasaan merokok & 26 & 18,5 \\
tidak merokok & 26 & 1,5 \\
1/2 sampai 1 pack per hari & 12 & 100,0 \\
1 sampai 2 pack per hari & 1 & \\
$>$ 2 pack per hari & 65 & \\
\hline Total & & \\
\hline
\end{tabular}


Tabel 2. Status Gizi, Risiko Anemia, dan Status Ketahanan Pangan Responden

\begin{tabular}{lcc}
\hline Karakteristik & Jumlah (orang) & Persentase (\%) \\
\hline Status Gizi & 5 & 7,7 \\
Kurus & 44 & 67,7 \\
Normal & 16 & 24,6 \\
Gemuk & & \\
\hline Risiko Anemia & 2 & 3,0 \\
resiko anemia (> 7 tanda klinis) & 63 & 97,0 \\
tidak resiko anemia (<7 tanda & & \\
klinis) & & \\
\hline Status Ketahanan Pangan & 25 & 38,5 \\
rendah & 36 & 55,4 \\
sedang & 4 & 6,1 \\
tinggi & & \\
\hline Tingkat Produktivitas & 3 & 4,6 \\
tidak produktif & 62 & 95,4 \\
Produktif & & \\
\hline
\end{tabular}

Pada Tabel 2, didapatkan data bahwa sejumlah 44 orang dari total 65 orang $(67,7 \%)$ pekerja memiliki status gizi yang normal. Sebaliknya untuk risiko anemia diketahui terjadi pada 2 dari 65 orang pekerja yang telah di periksa. Kondisi ketahanan pangan pada pekerja menunjukkan sebanyak $55 \%$ pekerja memiliki tingkat keragaman pangan sedang yang berarti mampu untuk mengkonsumsi jenis pangan yang berbeda sebanyak 4-5 jenis dalam kurun waktu satuhari terakhir. Selain itu sejumlah 38,5\% pekerja juga didapati masih rendah dalam tingkat keragaman pangan. Selain itu untuk tingkat produktivitas, ditemukan sejumlah 3 orang dari total 65 orang memiliki produktivitas yang rendah jika dibandingkan yang lainnya.

Hubungan antara status gizi, risiko anemia, dan status ketahanan pangan dengan produktivitas kerja pada pekerja bangunan dapat dilihat pada tabel 3. Tabel tersebut menjelaskan bahwa risiko anemia pada pekerja memiliki hubungan yang nyata dengan produktivitas pekerja dibuktikan dengan skor p-value $<0,05$. Hal ini diketahui melalui output pekerja yang beresiko anemia memiliki performa kerja yang lebih rendah jika dibandingkan pekerja yang lainnya. Performa kerja ini menjadi indikator penting dalam menilai produktivitas pada responden. Selain itu untuk status gizi dan status ketahanan pangan pada pekerja tidak menjelaskan adanya hubungan dengan produktivitas kerja. Kondisi status gizi dan ketahanan pangan pekerja tidak menjadi tolak ukur produktif atau tidaknya dalam bekerja, karena dalam pekerjaan konstruksi lebih terlihat melalui faktor pengalaman pekerja tersebut.

Risiko anemia pada pekerja ditandai melalui kelelahan, penurunan kapasitas dan produktivitas kerja (Maulidia, 2017). Hal ini sejalan pada penelitian yang dilakukan oleh Chester June, dkk pada pekerja konstruksi yang menyebutkan bahwa beberapa tanda gangguan klinis dalam kondisi malnutrition (anemia) akan berdampak kepada produktivitas dalam bekerja (Chesher et al., 1982). Dalam penelitian tersebut dilakukan uji status anemia melalui pemeriksaan kadar hemoglobin. Hal ini berbeda dalam penelitian ini yang menggunakan pemeriksaan tanda klinis sehingga tingkat sensitivitas akan berpengaruh terhadap hasil yang didapatkan. Selain itu, Suci (2009) dalam penelitiannya juga menunjukkan bahwa terdapat hubungan antara anemia dengan produktivitas pada pekerja. Laluyan (2016) dalam penelitiannya menjelaskan bahwa penilaian melalui asupan makan, dan aktivitas fisik akan menunjukkan seseorang memiliki resiko mengalami anemia. Hal ini juga ditemukan oleh Laluyan (2016) juga menjelaskan bahwa rendahnya asupan dengan diikuti aktivitas yang tinggi akan meningkatkan risiko anemia pada seseorang.

Kondisi status gizi yang kurang atau berlebih memiliki dampak yang langsung dalam hal kemampuan secara fisik, penurunan motivasi, lamban, hingga dapat menurunkan produktivitas kerja. Permasalahan status gizi yang kurang pada pekerja akan menyebabkan kondisi yang rentan dalam kelelahan, gangguan stress mental, hingga produktivitas yang menurun. Dalam penelitian ini menunjukkan tidak ada hubungan yang signifikan antara status gizi dan produktivitas kerja. Hal ini disebabkan karena tingkat kemampuan pekerja dalam menyelesaikan target kerja didasarkan atas pengalaman dalam bekerja. Selain itu, dalam penelitian yang dilakukan oleh Himaya (2019) menunjukkan adanya hubungan yang signifikan status gizi terhadap produktivitas kerja. Perbedaan status gizi pada pekerja tersebut akan berpengaruh terhadap tenaga dan kecepatan dalam menyelesaikan target yang telah ditentukan (Himaya, 2019).

Ketahanan pangan dalam penelitian ini berfokus kepada aspek konsumsi keragaman pangan harian yang dijalankan oleh pekerja. Sebagaimana yang dijelaskan oleh Suryana (2014) yang menyatakan bahwa dimensi penilaian ketahanan pangan seseorang secara umum terdiri atas ketersediaan bahan pangan, akses terhadap pangan, serta pemanfaatan pangan dalam bentuk konsumsi sehari-hari (Suryana, 2014). Dalam penelitian ini tidak didapatkan adanya hubungan antara ketahanan pangan dengan produktivitas dalam 
bekerja. Faktor utama yang menyebabkan ialah dalam akses terhadap pangan yang rendah pada pekerja yang menyebabkan kurangnya keberagaman dalam konsumsi pekerja. Hal ini berbeda jika dibandingkan dengan penelitian yang dilakukan oleh Okoye, dkk (2016) yang memperlihatkan adanya hubungan antara ketahanan pangan dengan produktivitas kerja. Perbedaan ini dimungkinkan ialah pada karakteristik responden yang berbeda dimana dalam pekerja bangunan mayoritas menunjukkan akses terhadap pangan yang cenderung rendah dengan kondisi dan keadaan di lingkungan kerja tersebut. Dalam studi lain yang dilakukan oleh Clayton, dkk (2016) menjelaskan bahwa mayoritas pekerja bangunan sering ditemukan memiliki tingkat ketahanan pangan yang rendah dibuktikan melalui asupan makan yang kurang beragam.

Tabel 3. Sebaran Data dan Hubungan Status Gizi, Risiko Anemia, dan Status Ketahanan Pangan dengan Produktivitas Pekerja Bangunan

\begin{tabular}{|c|c|c|c|c|c|}
\hline \multirow{3}{*}{ Karakteristik } & \multicolumn{4}{|c|}{ Produktivitas Kerja } & \multirow{3}{*}{ p-value (r-value) } \\
\hline & \multicolumn{2}{|c|}{ tidak produktif } & \multicolumn{2}{|c|}{ produktif } & \\
\hline & $\mathbf{n}$ & $\%$ & $\mathbf{n}$ & $\%$ & \\
\hline \multicolumn{6}{|l|}{ Status Gizi } \\
\hline Kurus & 0 & 0,0 & 5 & 7,7 & \multirow{4}{*}{0,826} \\
\hline Normal & 3 & 4,6 & 41 & 63,1 & \\
\hline Gemuk & 0 & 0,0 & 16 & 24,6 & \\
\hline Total & 3 & 4,6 & 62 & 95,4 & \\
\hline \multicolumn{6}{|l|}{ Risiko Anemia } \\
\hline Resiko anemia & 2 & 3,0 & 0 & 0,0 & \multirow{3}{*}{$0,000(\mathrm{r}=0,656)$} \\
\hline Tidak resiko anemia & 0 & 0,0 & 63 & 97,0 & \\
\hline Total & 2 & 3,0 & 63 & 97,0 & \\
\hline \multicolumn{6}{|l|}{ Status Ketahanan Pangan } \\
\hline Rendah & 0 & 0,0 & 25 & 38,5 & \multirow{4}{*}{0,282} \\
\hline Sedang & 3 & 4,6 & 33 & 50,8 & \\
\hline Tinggi & 0 & 0,0 & 4 & 6,1 & \\
\hline Total & 3 & 4,6 & 62 & 95,4 & \\
\hline
\end{tabular}

Penelitian ini dilakukan di tengah masa pandemi wabah Covid-19, sehingga dalam pelaksanaan pengambilan data diberlakukan beberapa protokol kesehatan yang telah ditetapkan pemerintah. Kelemahan dalam metode pengambilan data penelitian ini terdapat dalam proses penilaian status anemia yang terbatas pada pemeriksaan secara fisik klinis dengan membatasi kontak fisik dengan pekerja. Selain itu, terbatasnya akses waktu dan tempat yang memungkinkan peneliti hanya dapat melakukan pengambilan data informasi melalui daring atau online dengan responden.

\section{KESIMPULAN}

Terdapat hubungan pada status anemia dengan produktivitas kerja berdasarkan penilaian tanda fisik klinis. Sedangkan pada status gizi dan status ketahanan pangan tidak menunjukkan adanya hubungan dengan produktivitas pada pekerja. Perlu untuk dilakukan pemeriksaan kesehatan secara berkala kepada pekerja bangunan oleh penanggungjawab kontraktor supaya dapat dilakukan deteksi dini dan evaluasi terhadap pekerja. Untuk penelitian selanjutnya, dapat digunakan penilaian status anemia yang lebih sensitif seperti pengukuran kadar $\mathrm{Hb}$ untuk memperkuat hasil deteksi yang didapatkan.

\section{ACKNOWLEDGEMENT}

Peneliti mengucapkan rasa terima kasih kepada seluruh pihak yang terlibat terutama pihak developer perumahan Graha Natura yang telah memberikan ijin dan akses dilakukannya penelitian, Pelaksana proyek sebagai perantara informasi dengan pekerja, rekan-rekan mahasiswa yang bersedia membantu dalam proses pengambilan data serta para pekerja bangunan yang terlibat dalam kegiatan penelitian ini sehingga dapat terlaksana dengan baik dan lancar. 


\section{REFERENSI}

Census and Economic Information Center. Indonesia Labour Productivity Growth. (2017). Available at: https://www.google.com/amp/s/www.ceicdata.com/en/indicator/indonesia/labour-productivitygrowth/amp . (Accessed: 31st December 2019)

Badan Pusat Statistik. Produktivitas Tenaga Kerja Menurut Sub Sektor (Ribu Rupiah), 2008-2013. 2019 Available at: https://www.bps.go.id/statictable/2009/07/02/1056/produktivitastenaga-kerja-20012013-.html . (Accessed: 31st December 2019)

International Labour Organization. (2015).Improve Your Business: People and Productivity

Tisnawati, E. \& Kurniawan. (2005). Pengantar Manajemen, Jakarta: Kencana.

Astawa, G. (2015). Analisis Produktivitas Tenaga Kerja pada Pekerjaan Struktur Beton Balok dan Pelat Lantai. UNIVERSITAS UDAYANA.

Ratnawati, I. (2011). Pemenuhan Kecukupan Gizi Bagi Pekerja. Kesehatan Masyarakat: Kementerian Kesehatan.

Riyani, R. \& Ardyanto, D. (2016). Hubungan Status Gizi, Karakteristik Individu dengan Produktivitas Pekerja Sorting dan Packing. Universitas Airlangga.

Danan Surya Fitriananto, Widajanti, L., Aruben, R. \& Rahfiludin, M. Z. (2018). Gambaran Status Gizi Pekerja Bangunan Wanita di Kecamatan Tembalang Kota Semarang Tahun 2016. J. Kesehat. Masy. 6, 419-425

Fitri, L. (2016).Hubungan Pola Makan dengan Anemia pada Pekerja Wanita di PT. Indah Kiat Pulp and Paper (IKPP) Tbk. Perawang. J. Endur. 1, 152-157

Laluyan, R. E., Paruntu, M. E. \& Assa, Y. (2016). Gambaran Kadar Besi Darah pada Pekerja Bangunan. J. e-Biomedik 4,

Okoye B, C. \& Bachwenkizi, B. (2016). Analyses of Labour Productivity among Small-Holder Cassava Farmers for Food Security and Empowerment in Central Madagascar. Int. J. Agric. Manag. Dev. 3, 309-318

Sutomo, Purwaningsih, Y. \& Daerobi, A. Ketahanan Pangan Para Pekerja Sektor Industri di Kota Solo. EKO-REGIONAL 9,

Masturoh, I. \& Anggita, N. (2018). Metode Penelitian Kesehatan. Pusat Pendidikan Sumber Daya Manusia Kesehatan, Kementerian Kesehatan RI

Thamaria, N. (2017). Penilaian Status Gizi. Pusat Pendidikan Sumber Daya Manusia Kesehatan, Kementerian Kesehatan RI

Kementerian Kesehatan RI. (2019). Klasifikasi Status Gizi Menurut IMT. Direktorat Pencegahan dan Pengendalian Penyakit Tidak Menular (P2PTM), Kementerian Kesehatan Republik Indonesia

Aldine Independent School District. Anaemia Questionnaire for Ages 3-5 years old.

Kennedy, G., Ballard, T. \& Dop, M. (2013). Guidelines for Measuring Household and Individual Dietary Diversity. (Food and Agriculture Organization of the United Nations (FAO),

Kementerian Kesehatan RI. (2013). Angka Kecukupan Gizi: Energi, Protein yang Dianjurkan bagi Bangsa Indonesia.

Disnaketrans Provinsi Jatim. (2020). Surat Keputusan Gubernur Jatim Nomor 188/568/KPTS/2019:Besaran UMK Jawa Timur

World Health Organization (WHO). (2011). Haemoglobin Concentrations for The Diagnosis of Anaemia and Assessment of Severity.

Maulidia, F. (2017).Analisa Produktivitas dan Faktor yang Mempengaruhi Kinerja Tukang pada Pemasangan Bata dengan Metode Productivity Rating. (Universitas Muhammadiyah Malang

Chesher, A.. (1982)Worker Productivity and the Nutritional Status of Kenyan Road Construction Worker Kenyan productivity and the nutritional road construction status of. Am. J. Clin. Nutr. 68-78 . doi:10.1093/ajcn/36.1.68

Himaya. (2019). Hubungan Pola Konsumsi, Kecukupan Gizi, dan Status Gizi dengan Produktivitas Kerja (PT. Timur Megah Steel Gresik Tahun 2019): Universitas Airlangga.

Suryana, A. (2014). MENUJU KETAHANAN PANGAN INDONESIA BERKELANJUTAN 2025: TANTANGAN DAN PENANGANANNYA Toward Sustainable Indonesian Food Security 2025 : Challenges and Its Responses. FORUM Penelit. AGRO Ekon. 32, 123-135

Muhammad, H. (2014). Symptoms-Based Evaluation of Iron Deficiency Anemia in Students of Bahawalpur Correlated with their Eating Habits. 13, 769-772

Gibson. (2005). Principles of Nutrition Assesment, 2nd Edition. USA: Oxford University Press.

Clayton, E. (2016). Nutritional and Food Insecurity of Construction Workers. Natl. Libr. Med. PubMed.gov doi:10.3233/WOR-162335

Almatsier, S. (2009).Prinsip Dasar Ilmu Gizi. Jakarta:Penerbit PT Gramedia Pustaka Utama

Ervianto, W. I. (2009).Manajemen Proyek Konstruksi: Penerbit ANDI. 
Widyaji, S. K. (2017). 'Hubungan Ketahanan Pangan Rumah Tangga dan Infeksi Cacing Tambang dengan Kejadian Anemia pada Penambang Pasir Tradisional di Desa Pronojiwo Kecamatan Pronojiwo Kabupaten Lumajang': Universitas Airlangga.

Suci. (2009) Hubungan Anemia dan Status Gizi pada Produktivitas Kerja (Studi Pekerja Wanita di Bagian Pengobrasan 'Home Industry' Sarung Tangan PT.Pelita Trijaya Rizki di Kecamatan Driyorejo Kabupaten Gresik): Universitas Airlangga

Oglesby. (1988). Productivity Improvement In Construction. (Penerbit McGraw Hill Series In Construction Engineering and Project Management 